\title{
Inhibiting Downstream Signaling Pathway of FIT3 in Acute Myeloid Leukemia
}

\section{Akut Myeloid Lösemide FLT3 Sinyalizasyon Yolakının Akış Yönünde İnhibisyonu}

\author{
Research Article
}

\section{Gledjan Caka*, Mynyr Koni ${ }^{2}$}

'Department of Biotechnology, Faculty of Natural Sciences, University of Tirana, Albania.

2Department of Biology, Faculty of Natural Sciences, University of Tirana, Albania.

\section{A B S TR AC T}

- LT3 is a type 3 tyrosine kinase receptor susceptible to different genetic mutations in acute myeloid leukeF mia. Several studies have shown that a large number of patients (approximately one third) have mutations of this gene, lead of which is internal tandem duplications (ITD) that leads to activation of downstream signaling pathway and abnormal cellular growth. We used specific target inhibitors to elucidate the combined effects of NOX4 inhibition and the inhibition of FLT3-ITD tyrosine kinase on FLT3-ITD signal transduction.

\section{Key Words}

FLT3, tyrosine kinase, inhibitor.

\section{öz}

\begin{abstract}
E LT3 akut miyeloid lösemide farklı genetik mutasyonlara duyarlı tip 3 tirozin kinaz reseptörüdür. Birçok - çalışma, çok sayıda hastada (yaklaşık üçte biri) bu genin mutasyona uğradığını göstermiştir; bunun nedeni aşağı akış sinyal yolağı ve anormal hücre çoğalmasının yol açtığı iç tandem duplikasyonlardır (ITD). Bu çalışmada, NOX4 inhibisyonunun kombine etkilerini ve FLT3-ITD sinyal iletiminde FLT3-ITD tirozin kinazın inhibisyonunu aydınlatmak için özgül hedef inhibitörleri kullanılmıştır.
\end{abstract}

\section{Anahtar Kelimeler}

FLT3, tirozin kinaz, inhibitör.

Article History: Received: Aug 2, 2016; Revised: Sep 25, 2016; Accepted: Jan 20, 2017; Available Online: Apr 1, 2017. DOI: $10.15671 /$ HJBC.2017.160

Correspondence to: G. Caka, Department of Biotechnology, Faculty of Natural Sciences, University of Tirana, Albania 


\section{INTRODUCTION}

The he class III receptor tyrosine kinase (RTK) family consists of FLT3, KIT, FMS, and the two PDGF receptors. The members of this receptor family play important roles in cell growth, survival and development in hematopoiesis. The class III receptors share structural characteristics including five extracellular immunoglobulin-like domains, a single transmembrane domain and a kinase domain interrupted by a kinase insert $[1,2]$. FLT3 (FMS-like tyrosine kinase 3) is a member of the class III receptor tyrosine kinase family. FLT3 is preferentially expressed on hematopoietic stem/progenitor cells as well as dendritic cell precursors. Binding of FLT3 ligand (FL) to FLT3 results in receptor dimerization, activation of the intrinsic tyrosine kinase activity and receptor autophosphorylation [3]. Approximately one third of the acute myeloid leukemia (AML) patients have genetic alterations of this gene and are one of the most frequent mutations identified in AML [4]. Genetic mutations of in the leukemic stem cells include mutations in genes controlling cell proliferation and apoptosis, cytogenetic aberrations and epigenetic regulators [5]. The majority of these mutations involve the internal tandem duplications in the juxtamembrane (JM) domain of FLT3 specifically found in AML patients [6]. FLT3-ITD is prevalent ( 50\%) in patients with translocations of $\mathrm{t}(15 ; 17)$ [7]. FLT3-ITD mutations result in the activation of FLT3 kinase. Genetic alterations in the FLT3 JM lead to the activation loop and the loss of autoinhibitory functions of the cell, which in turn activates the FLT3 kinase and its downstream proliferative signaling pathways, including the Ras/MAPK kinase, the ERK $1 / 2$ pathway and the PI3K-AKT kinase pathway [5]. This is also done by the wild-type FLT3 (WTFLT3) signal. In addition and in contrast to WTFLT3, FLT3-ITD also phosphorylates and strongly activates the STAT5 pathway [8]. STAT5 induces the cyclin D1 and p21 genes which are important for cell growth [9] and this indicates the role of FLT3-ITD in the aberrant cell growth of leukemia cells. The occurrence of FLT3-ITD mutations is associated with poor prognosis and FLT3 kinase inhibitors such as midostaurin or the potent compound AC220 (quizartinib) are currently being tested in clinical trial $[10,11]$. The presence of FLT3/ITD mutations in patients with AML is associated with lower cure rates when these patients are treated with standard chemotherapybased regimens [12-14]. In vitro work has shown that targeting the mutation by inhibiting the tyrosine kinase activity of FLT3 is cytotoxic to cell lines and to primary AML cells harboring FLT3 mutations [15-17].

A study by Yokota et al. [18] showed that mutations in the ITD JM were found in $17-34 \%$ of AML patients and $5 \%$ in myelodysplastic patients (MDS). The data supporting the involvement of activated FLT3 in leukemia lead to the search for an inhibitor of the tyrosine activity to use as a therapeutic intervention. We used GKT137831, a potent inhibitor of NOX1/NOX4 and a potent inhibitor of fibrosis and hepatocyte apoptosis and an $\mathrm{IC}_{50}$. We also used another inhibitor, AG1295, an inhibitor selectively toxic to primary leukemic blasts from cells harboring a FLT3-ITD mutation [19]. In this study we examined the downstream signaling of FLT3-ITD from MV4-11 cell line. The responses of these cells expressing FLT3-ITD were correlated with changes in signal transduction, cell proliferation and apoptosis.

\section{MATERIALS and METHODS}

\section{Cellular Assays}

The MV4-11 human cell line was grown in RPMI 1640 supplemented with $10 \%$ fetal bovine serum. For proliferation assays, cells were cultured overnight in low serum media (0.5\% FBS), then seeded in a 6-well plate at 100000 cells per well. Inhibitors were added to the cells and incubated at $37^{\circ} \mathrm{C}$ for 24 hours. Cell viability was measured using the Cell Titer-Blue Cell Viability Assay from Promega. To measure inhibition of FLT3 autophosphorylation, cells were cultured in low serum media ( $0.5 \% \mathrm{FBS}$ ) overnight and seeded at a density of $24 \times 10^{6}$ cells per well in a 6 -well plate the following day. The cells were incubated with inhibitors for 24 hours at $37^{\circ} \mathrm{C}$. The cells were lysed and immunoprecipated by incubation with antibodies for PY591, FLT3, STAT5, AKT and ERK.

\section{Apoptosis Assay}

Mv4-11 cells were diluted to a $2 \times 10^{5}$ cells $/ \mathrm{ml}$ in RPMI 1640 medium, in the absence of IL-3. Cells were seeded in 12 well plate and the inhibitors 
were added 24 hours at $37^{\circ} \mathrm{C}$ for the AG1295 and 1 hour for AC220, in different concentrations. After the incubation AnnexinV was added for staining and the analysis was done by FACS.

\section{RESULTS}

FLT3-ITD causes upregulation of NOX expression. In order to determine the ability of the compounds to inhibit the FLT3 signal in the cells we measured the autophosphorylation in the leukemia human cell lines MV4-11, which harbors a homozygous FLT3-ITD mutation. To verify how the inhibitors worked we used different concentrations of the inhibitors and combined them to see the effects they had on the FLT3 signaling. In order to check if the signal was there and that the FLT3-ITD proteins were expressed we used SDS PAGE and immunoblotting and we found that these proteins were present in the cell lysates as shown in Figure 1.

These data suggest that AG1295 is an inhibitor of FLT-ITD kinase activity in the cells that express these mutations. The activation of many cytokine receptors induces the tyrosine phosphorylation of proteins in the JAK-STAT signal transduction pathway [20]. Phosphorylation of STAT has always been fund in leukemia patients and has been implicated in leukemogenesis. To further determine the presence of FLT3-ITD we also tested the lysates for different antibodies (STAT5, AKT, ERK) to check that the result was indeed inhibited by the AG1295 compound as shown in Figure 2.

So in order to determine the inhibition of

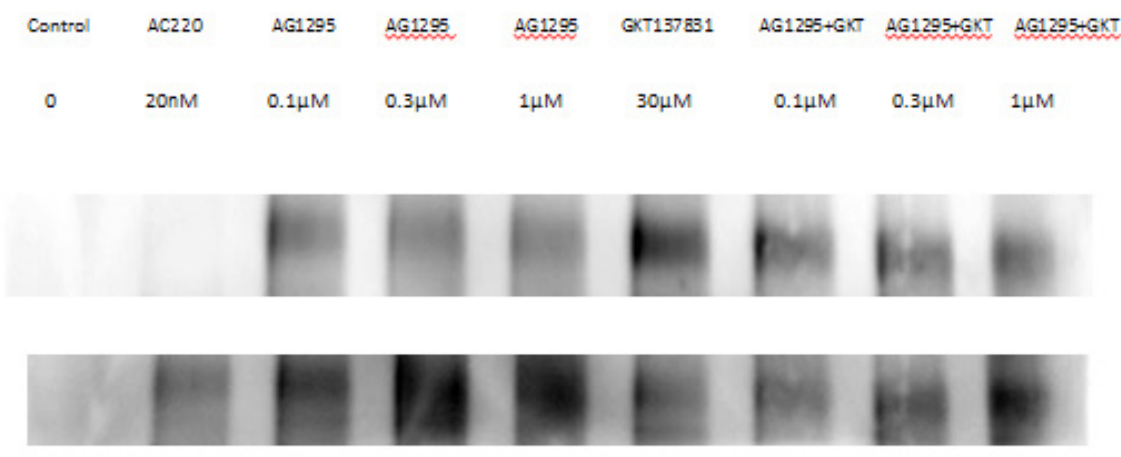

PY591

FLT3

Figure 1. Tyrosine phosphorylation of FLT3-ITD in MV4-11 cells and inhibition by AG1295. Cells were lysed and immunoprecipitated with antibodies for FLT3 and run in a SDS PAGE.

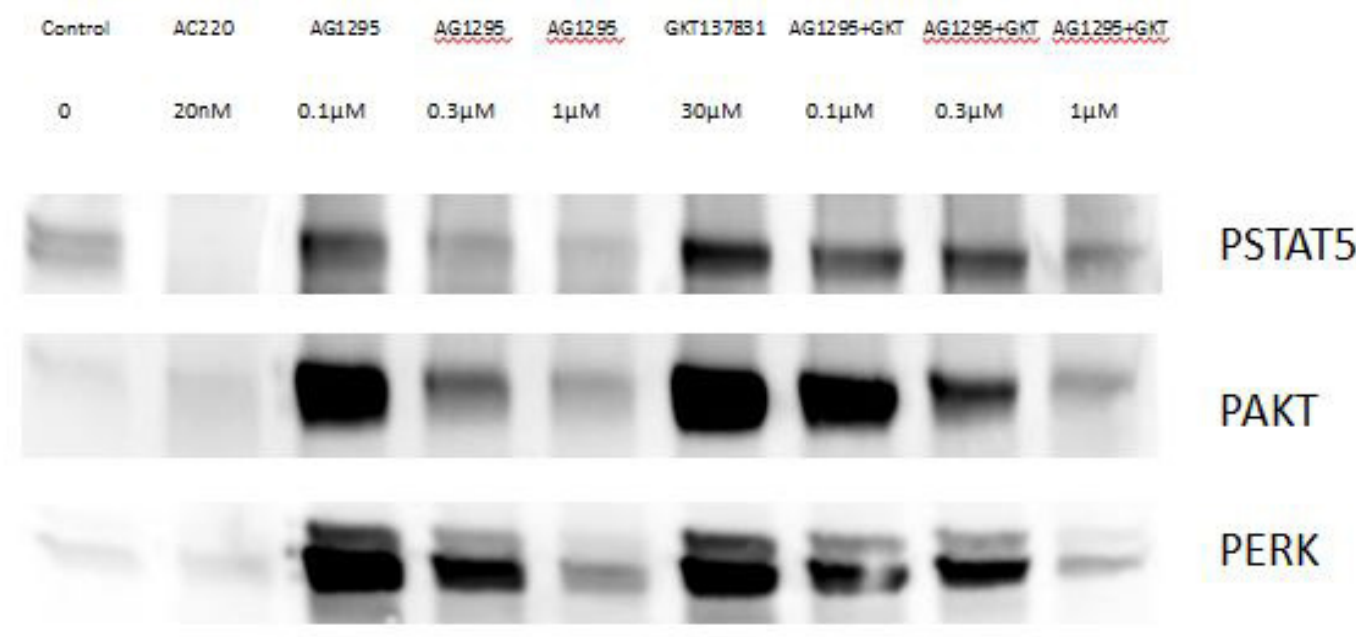

Figure 2. Phosphorylation of FLT3-ITD also induces phosphorylation of STAT5, AKT and ERK which were immunoprecipated and run by PAGE. AG1295 promotes the FLT3 in the membrane. When we see the phosphorylation of STAT5 we see that FLT-ITD is retained in the endoplasmic reticulum (ER). And the phosphorylation of AKT and ERK indicate the presence of FLT-ITD in the cell membrane. 


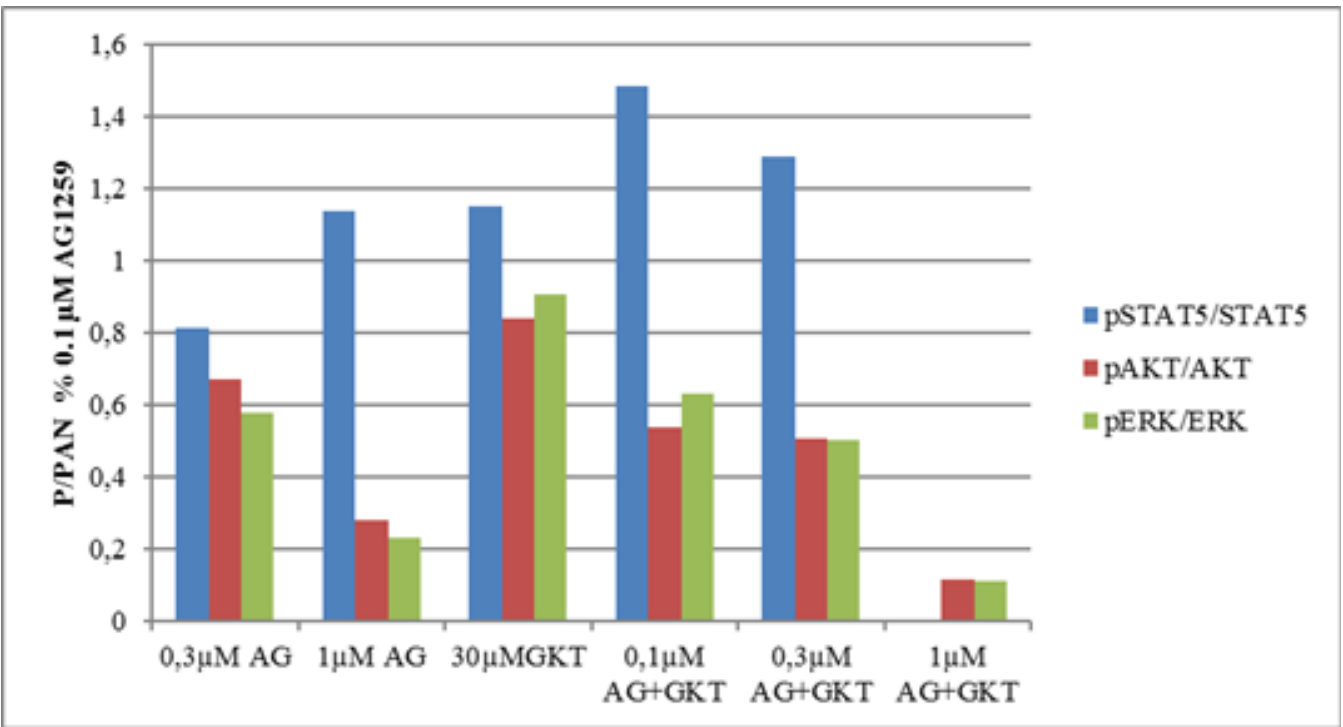

Figure 3. Effect of kinase NOX4 inhibition on signaling in MV4-11 in the P/PAN of the cells.

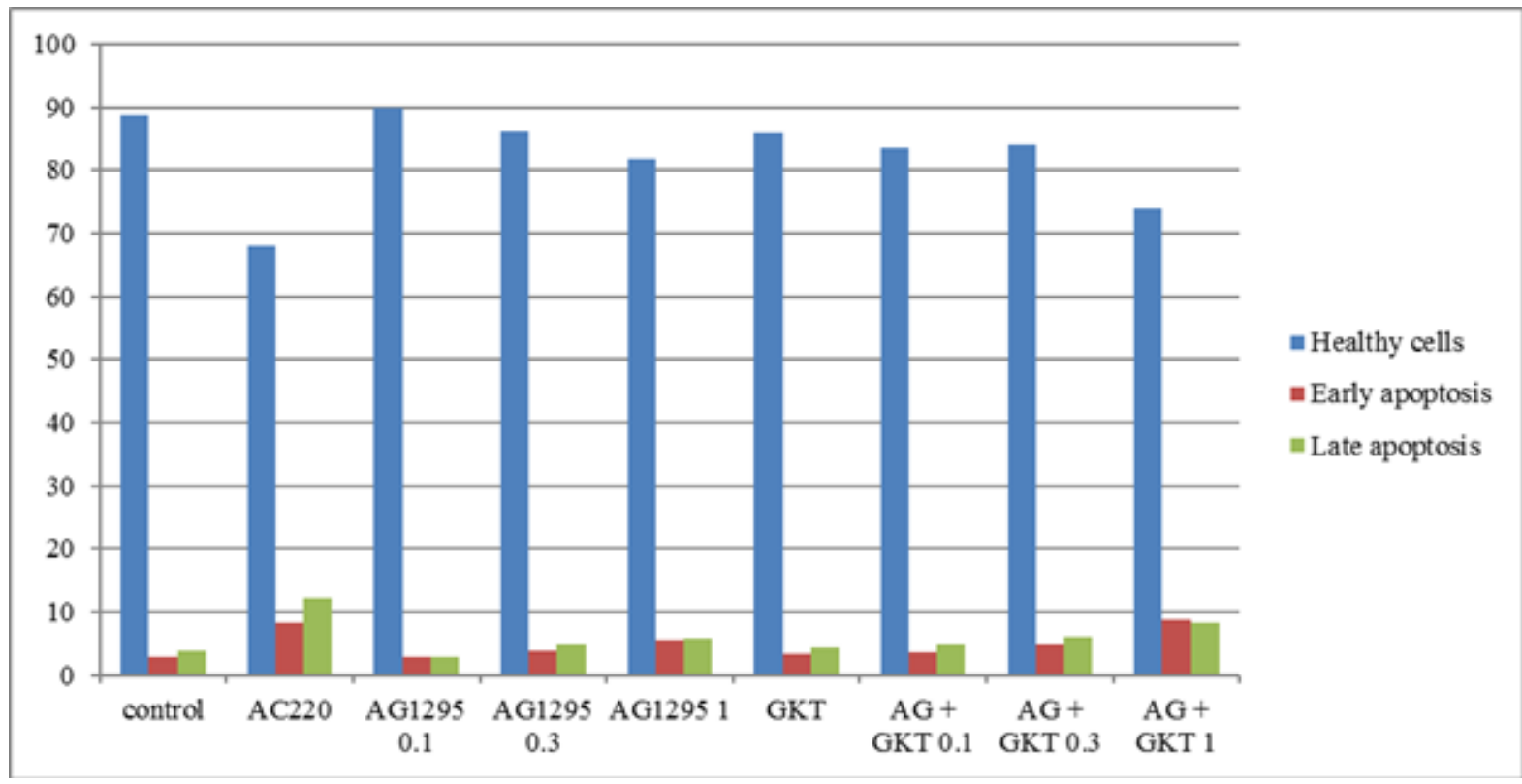

Figure 4. Inhibition of cell proliferation in cells expressing FLT3-ITD by AG1295. The cells were treated with IL-3 with different concentrations as shown above and the results were measured. We see a shift in the graph in correlation to a dose-dependent manner.

FLT3-ITD we also used GKT to check the effects of NOX4 inhibition on the MV4-11 cells signaling as shown in Figure 3.

We wanted to determine that the inhibition of FLT3-ITD by AG1295 would also inhibit cell proliferation and induce apoptosis of the FLT3ITD transformed MV4-11 cells, so we did an MTS assay in order to confirm our suspicions. Cells were treated with AG1295 in a dose-dependent manner ranging from $1 \mu \mathrm{M}$ to $10 \mu \mathrm{M}$ in combination with GKT which we used at a concentration of 10 $\mu \mathrm{M}$ and in the presence of IL-3. The presence of AG1295 inhibited the proliferation of cells which expressed the FLT-ITD strain in a dose-dependent manner. We also saw a little inhibition of the parental cells which indicate that these inhibitors show a cytotoxic effect to MV4-11 cells as shown in Figure 4. 


\section{DISCUSSION}

Genetic alterations of FLT3 constitutively activate the tyrosine kinase activity in $\mathrm{AML}$ patients. Studies have shown that patients who harbor these mutations have a poor prognosis, eventually leading to death. The studying of the pharmaceutical and molecular activity of these inhibitor drugs for the tyrosine activity of FLTITD may lead to better treatment of patients and increasing the survivability rate of patients. Using AG1295 as a compound to inhibit FLT3ITD signaling we determined that AG1295 has good anti-leukemic activity in MV4-11 cells. It inhibits cell proliferation and also results in apoptosis of cells expressing the FLT3-ITD strain. This may result from the inhibition of the FLTITD signal which activates and phosphorylates many downstream signaling proteins, especially STAT5. We also found that AG1295 inhibits FLT3 autophosphorylation in cells harboring the FLT3ITD mutations, but that it also has a cytotoxic effect in higher concentrations.

Understanding the molecular pathways of the FLT3 signaling and how to block it's tyrosine activity would allow us to develop more specific inhibitors with greater bioavailability to be used in the future for the treatment of leukemia patients.

\section{References}

1. W. Matthews, C.T. Jordan, G.W. Wiegand, D. Pardoll, I.R. Lemischka, A receptor tyrosine kinase specific to hematopoietic stem and progenitor cell-enriched populations, Cell, 65 (1991) 1143-1152.

2. O. Rosnet, D. Birnbaum, Hematopoietic receptors of class III receptor-type tyrosine kinases, Crit. Rev. Oncog., 4 (1993) 595-613.

3. B.D. Smith, M. Levis, M. Beran, F. Giles, H. Kantarjian, K. Berg, K.M. Murphy, T. Dauses, Jeffrey Allebach, D. Small, Single agent CEP-701, a novel FLT3 inhibitor, shows biologic and clinical activity in patients with relapsed or refractory acute myeloid leukemia, Blood, doi: https://doi.org/10.1182/blood-2003-11-3775.

4. Cancer Genome Atlas Research Network, Genomic and epigenomic landscapes of adult de novo acute myeloid leukemia. N. Engl. J. Med., 368 (2013) 2059-2074.
5. C. Hannum, J. Culpepper, D. Campbell, T. McClanahan, S. Zurawski, J.F. Bazan, R. Kastelein, S. Hudak, J. Wagner, J. Mattson, Ligand for FLT3/FLK2 receptor tyrosine kinase regulates growth of haematopoietic stem cells and is encoded by variant RNAs, Nature, 368 (1994) 643-648.

6. S. Yokota, H. Kiyoi, M. Nakao, T. Iwai, S. Misawa, T. Okuda, Y. Sonoda, T. Abe, K. Kahsima, Y. Matsuo, T. Naoe, Internal tandem duplication of the FLT3 gene is preferentially seen in acute myeloid leukemia and myelodysplastic syndrome among various hematological malignancies. A study on a large series of patients and cell lines, Leukemia, 11 (1997) 16051609.

7. N.I. Noguera, M. Breccia, M. Divona, D. Diverio, V. Costa, S.D. Santis, G. Avvisati, M.B. Pinazzi, M.C. Petti, F. Mandelli, F.L. Coco, Alterations of the FLT3 gene in acute promyelocytic leukemia: association with diagnostic characteristics and analysis of clinical outcome in patients treated with the Italian AIDA protocol, Leukemia, 16 (2002) 2185-2189.

8. M. Mizuki, J. Schwable, C. Steur, C. Choudhary, S. Agrawal, B. Sargin, B. Steffen, I. Matsumura, Y. Kanakura, F.D. Bohmer, Suppression of myeloid transcription factors and induction of STAT response genes by AMLspecific Flt3 mutations, Blood, 101 (2003) 3164-3173.

9. V. Calo, M. Migliavacca, V. Bazan, M. Macaluso, M. Buscemi, N. Gebbia, A. Russo, STAT proteins: from normal control of cellular events to tumorigenesis, J. Cell. Physiol. 197 (2003) 157-168.

10. C.C. Smith, Q. Wang, C.S. Chin, S. Salerno, L.E. Damon, M.J. Levis, Validation of ITD mutations in FLT3 as a therapeutic target in human acute myeloid leukaemia, Nature, 485 (2012) 260-263.

11. R.M. Stone, T. Fischer, R. Paquette, G. Schiller, C.A. Schiffer, G. Ehninger, Phase IB study of the FLT3 kinase inhibitor midostaurin with chemotherapy in younger newly diagnosed adult patients with acute myeloid leukemia, Leukemia, 26 (2012) 2061-2068.

12. P.D. Kottaridis, R.E. Gale, M.E. Frew, The presence of a FLT3 internal tandem duplication in patients with acute myeloid leukemia (AML) adds important prognostic information to cytogenetic risk group and response to the first cycle of chemotherapy: analysis of 854 patients from the United Kingdom Medical Research Council AML 10 and 12 trials, Blood, 98 (2001) 1752-1759.

13. H. Kiyoi, T. Naoe, Y. Nakano, Prognostic implication of FLT3 and N-RAS gene mutations in acute myeloid leukemia, Blood, 93 (1999) 3074-3080.

14. S. Meshinchi, W.G. Woods, D.L. Stirewalt, Prevalence and prognostic significance of Flt3 internal tandem duplication in pediatric acute myeloid leukemia, Blood, 97 (2001) 89-94.

15. K.F. Tse, J. Allebach, M. Levis, Inhibition of the transforming activity of FLT3 internal tandem duplication mutants from AML patients by a tyrosine kinase inhibitor, Leukemia, 16 (2002) 2027-2036. 
16. M. Levis, J. Allebach, K.F. Tse, A FLT3-targeted tyrosine kinase inhibitor is cytotoxic to leukemia cells in vitro and in vivo, Blood, 99 (2002) 3885-3891.

17. M. Levis, K.F. Tse, B.D. Smith, E. Garrett, D.A. Small, FLT3 tyrosine kinase inhibitor is selectively cytotoxic to acute myeloid leukemia blasts harboring FLT3 internal tandem duplication mutations, Blood, 98 (2001) 885-88.

18. S. Yokota, H. Kiyoi, M. Nakao, T. Iwai, S. Misawa, T. Okuda, Y. Sonoda, T. Abe, K. Kahsima, Y. Matsuo, T. Naoe, Internal tandem duplication of the FLT3 gene is preferentially seen in acute myeloid leukemia and myelodysplastic syndrome among various hematological malignancies. A study on a large series of patients and cell lines, Leukemia, 11 (1997) 16051609.
19. M. Levis, K.F. Tse, B.D. Smith, E. Garrett, D.A. Small, A FLT3 tyrosine kinase inhibitor is selectively cytotoxic to acute myeloid leukemia blasts harboring FLT3 internal tandem duplication mutations, Blood, 98 (2001) 885-887.

20. J.E. Darnell, I.M. Kerr, G.R. Stark, Jak-STAT pathways and transcriptional activation in response to IFNs and other extracellular signaling proteins, Science, 264 (1994) 1415-1420. 